\title{
Small countries receive even less of a fair deal
}

\section{Governments and companies should intervene to control the price of lab supplies.}

Sir — We welcome your Editorial "A fair deal for all” accompanying the survey reported in "High prices of supplies drain cash from poorer nations' labs" (Nature 428, 451 and 453; 2004).

These address a topic of great importance to scientific researchers in less developed countries. Recognizing this problem is the first step towards finding and implementing some solutions.

Your survey compared the costs of laboratory equipment and materials in four countries - Germany, Poland, the United States and Brazil - and revealed some differences between the poorer and wealthier nations. Poland is, however, the largest market in Eastern Europe; in smaller markets, such as Croatia, the situation can be even worse for scientists.

When prices of laboratory equipment and materials in Croatia are compared with those in wealthier states, the differences turn out to be still more pronounced. There are, for sure, a few items that are exceptions to this general rule, but in our experience most lab equipment and materials show similar, if not bigger, price differences.

For example: in Croatia, $500 \mathrm{~g}$ albumin, bovine fraction $\mathrm{V}$ protease-free, costs approximately $€ 1,458$ (US\$1,796) compared with the manufacturer's price of $€ 992$ (using an exchange rate of 7.5 kuna to the euro and excluding value-added tax). Similarly, $0.5 \mathrm{ml}$ mouse monoclonal anti-fish CYP1A peptide costs about $€ 1,112$ in Croatia, compared with the producer's price of $€ 480$.

These represent the best prices that we have found for these supplies.

One should also consider the low levels of research funding in poorer countries. In Croatia, the government's expenditure on research grants is many times lower than in more affluent states.

For this reason, it is no exaggeration to say that the only way a research group from one of Europe's poorer nations can publish its work in prestigious journals is to collaborate with Western researchers, who benefit from higher funding and lower costs of materials.

In Croatia, the prices of laboratory equipment and materials could be controlled by the state to prevent local distributors selling products at inflated prices. In addition, the producers themselves could intervene and encourage local distributors to sell at the manufacturer's price.

This would help eastern European researchers get better value for their money, making the scientific game a little more just.

Stipan Jonjic ${ }^{\star}$, Luka Traven $\dagger$

${ }^{\star}$ Department of Histology and Embryology,

Faculty of Medicine, University of Rijeka,

Brace Branchetta 20a, 51000 Rijeka, Croatia tDepartment of Environmental Health,

Faculty of Medicine, University of Rijeka,

Brace Branchetta 20a, 51000 Rijeka, Croatia

\section{Fair deal: local factors add to price of supplies}

Sir - In response to your News story "High prices of supplies drain cash from poorer nations' labs" (Nature 428, 453 ; 2004), I would like to make clear that Amersham Biosciences (now GE Healthcare) maintains a transparent and consistent pricing policy as part of its ongoing commitment to the global scientific community and customer service.

As with any international business, many factors can cause differences in the final price paid, such as currency valuations, quantities, import duties, local taxes, distribution channels and the local competitive situation.

The list prices of the two Amersham Biosciences products that were highlighted in this News story - the EPS 601 power supply and the Ultrospec 3300 pro spectrometer - are actually consistent across those markets (allowing for currency fluctuations).

Below are the list prices we publish in the relevant currency for the four countries quoted in your News story.

EPS 601:

United States and Brazil US\$963;

Germany and Poland €860.

Ultrospec 3300:

United States \$12,187; Brazil US\$11,812;

Germany and Poland €8,680.
Our list prices are publicly available in our catalogue and online, and are broken down by region. Because of fluctuations in currency valuation, these should not be represented in any one currency for different regions.

Andrew Carr

GE Healthcare, 800 Centennial Avenue,

Piscataway, New Jersey 08855, USA

\section{Fair deal foiled by taxes and exchange rates}

Sir - We would like to provide some information to contest the statements about Eppendorf products made in your recent News story about the price of laboratory supplies in poorer countries (Nature 428, 453; 2004).

The Brazilian price stated for a centrifuge 5415D (US\$3,110) is not the regular price for this item. The centrifuge $5415 \mathrm{D}$ is sold in local markets by our official dealers on average for $\$ 2,500$. Some research institutes are able to import products directly in order to avoid taxes. In this case, the centrifuge would cost $\$ 2,100$.

It should be noted that Brazil has a very high tax burden (14\% import taxes, $8 \%$ manufactured taxes, $18 \%$ sales tax). These taxes occur in cascade and must be paid when the dealer receives the product (each tax is added on top of the previous tax).
Depending on the product, these taxes amount to $50-60 \%$ of the final product price. There is currently no legislation to assist researchers buying scientific products, although clinical labs profit from a law granting certain tax benefits.

As Eppendorf is a European company, there is always some variation in price due to the exchange rates. Dealers buy products from Eppendorf in euros, whereas Brazilians are more used to US dollars or their own currency, the real (R\$). So we should take into consideration a series of exchange rates: $\mathrm{R} \$ 3.79$ to the euro, $\mathrm{R} \$ 3.17$ to the dollar and US\$1.20 to the euro. At present, this situation is extremely unfavourable for us.

Finally, there are non-authorized companies selling Eppendorf products in Brazil, whose prices we cannot control. Josely Chiarella Eppendorf do Brasil Ltda.,

Praca Panamericana no. 42, Conj. 13, 05461.000 Alto de Pinheiros, Sao Paulo-SP, Brazil

The aim of our news coverage was to discover what prices researchers in different countries actually have to pay for a given piece of equipment. So we asked the researchers in each country to contact their authorized local retailers, just as they would under normal circumstances. The prices quoted in our story therefore reflect the authentic quotes they received - Editor, Nature. 